\title{
EXPERIMENTAL MODELLING OF ASPHALTIC LAYERS BEHAVIOUR AT REFLECTIVE FRACTURE FROM DEGRADED PA VEMENTS - PARAMETRIC STUDIES
}

Mihai Gabriel LOBAZӑ, Eng. Assistant Prof. , PhD student, Faculty of Railways, Roads and Bridges, Technical University of Civil Engineering Bucharest, email: mihail@cfdp.utcb.ro

Mihai DICU, PhD Eng. Professor, Faculty of Railways, Roads and Bridges, Technical University of Civil Engineering Bucharest, email: $\underline{\text { mdicu@ cfdp.utcb.ro }}$

\section{Rezumat}

Datorită degradării în timp a îmbrăcăminților rutiere, trebuiesc adoptate măsuri pentru reabilitarea acestora cu costuri cât mai mici. Una din soluțiile des utilizate îl reprezintă aşternerea covoarelor asfaltice peste cele degradate. Problema principală care apare în cazul acestei soluții este transmiterea fisurilor din stratul existent în covorul de protecție (fisurare reflectivă).

Adoptarea soluției optime în cazul straturilor asfaltice de protecție, din punct de vedere al comportării la fisurare, scade considerabil costurile de întreținere/reabilitare a structurii rutiere existente. De aceea sunt necesare studii experimentale efectuate în laborator, care presupune costuri mici, dar și o perioadă mai scurtă de timp faţă de sectoarele experimentale.

În cadrul încercărilor de laborator efectuate, s-a urmărit și măsurat parametrii fisurării: deschiderea și lungimea fisurii în mixtură, deschiderea fisurii betonului, deformația probei și numărul de cicluri. Interpretarea acestor parametri, prin stabilirea unor legi de evoluție a acestora, ne poate oferi o imagine a modului în care fisura se transmite din betonul de ciment prefisurat în stratul de protecție și apoi se propagă pe întreaga grosime a acestuia.

Se poate astfel stabili care este rețeta de mixtură asfaltică care se comportă cel mai bine la acest tip de fisurare, evitându-se astfel adoptarea unei soluții neadecvate care atrage după sine costuri ridicate de întreținere.

Cuvinte cheie: Încărcări din trafic, fisurare reflectivă, parametrii fisurării.

\section{Abstract:}

Due to the pavement degradation in time, rehabilitation measures need to be adopted, maintaining the costs as lower as it can. One of the solutions often utilized is to apply a layer of asphalt concrete over the degraded pavement. The main issue of this method is that the fractures which exists in the old pavement are transmitted in the asphaltic overlay (reflective fracture). 
ROMANIAN JOURNAL

OF TRANSPORT INFRASTRUCTURE

Lobază Mihai Gabriel, Dicu Mihai,

Experimental modelling of asphaltic layers behaviour at reflective fracture from degraded pavements Parametric studies

By adopting the optimal solution for the overlay, from the fracture's behavior perspective, the maintenance/rehabilitation costs are considerably reduced. This is why experimental laboratory studies are needed to be conducted. They are cheaper and are less time-consuming than the experimental field studies.

The fracture parameters were measured in the laboratory: the opening and length of the overlay fracture, opening of the existing pavement fracture, the specimen deformation, time (number of cycles). The interpretation of this parameters can give us an image of the way the fracture is transmitted from the old pavement to the asphaltic overlay and then it propagates trough the entire overlay thickness.

This is the way the asphaltic mixture recipe that best behaves to this type of fracture can be established, avoiding an inadequate mixture design which involves higher maintenance costs.

Keywords: Traffic Load, reflective fracture, fracture parameters.

\section{MODELLING ANALYSIS OF THE REHABILITATED ROAD STRUCTURES AT TRAFFIC LOADS STRESS}

Anticipating the behaviour of the asphaltic road materials, utilized as overlays for the rehabilitation or maintenance of damaged road pavement, represents one of the objectives of road infrastructure specialists.

Complex laboratory analyzes, capable of simulating the effects of real traffic loads, can be finalized by obtaining a new faster and cheaper approach, different than the classic tests, to assess the lifecycle of the asphaltic overlay (in this paper a used concrete pavement is taken into consideration). Also it can be anticipated the fracture behaviour of the overlay.

Thus, through accelerated tests for simulating traffic by experimental modelling, we aim to obtain the performance of the optimum recipe solutions designed in the laboratory for the asphaltic overlay.

Repeated loads, especially those given by heavy traffic, produce an accumulation of residual deformations and fatigue in materials used in road structure, materials which suffers structural damages.

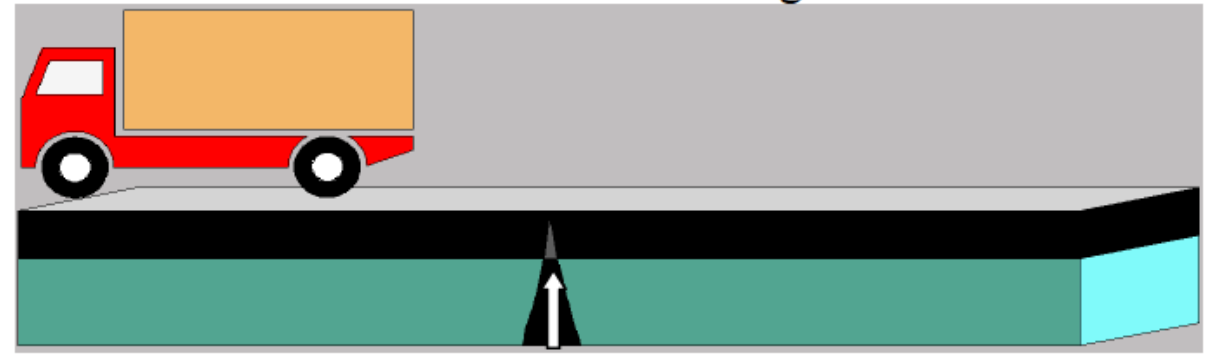

Figure 1. Reflective cracking principle from cement concrete to asphaltic overlay 
ROMANIAN JOURNAL

OF TRANSPORT INFRASTRUCTURE

Lobază Mihai Gabriel, Dicu Mihai,

Experimental modelling of asphaltic layers behaviour at reflective fracture from degraded pavements Parametric studies

Modelling an object through phenomenological laboratory simulation, involves a reduction in the geometric dimensions found in reality, necessary for the experimental research. In this paper the constructive contact elements between a vehicle and the road surface are analysed (figure 2).
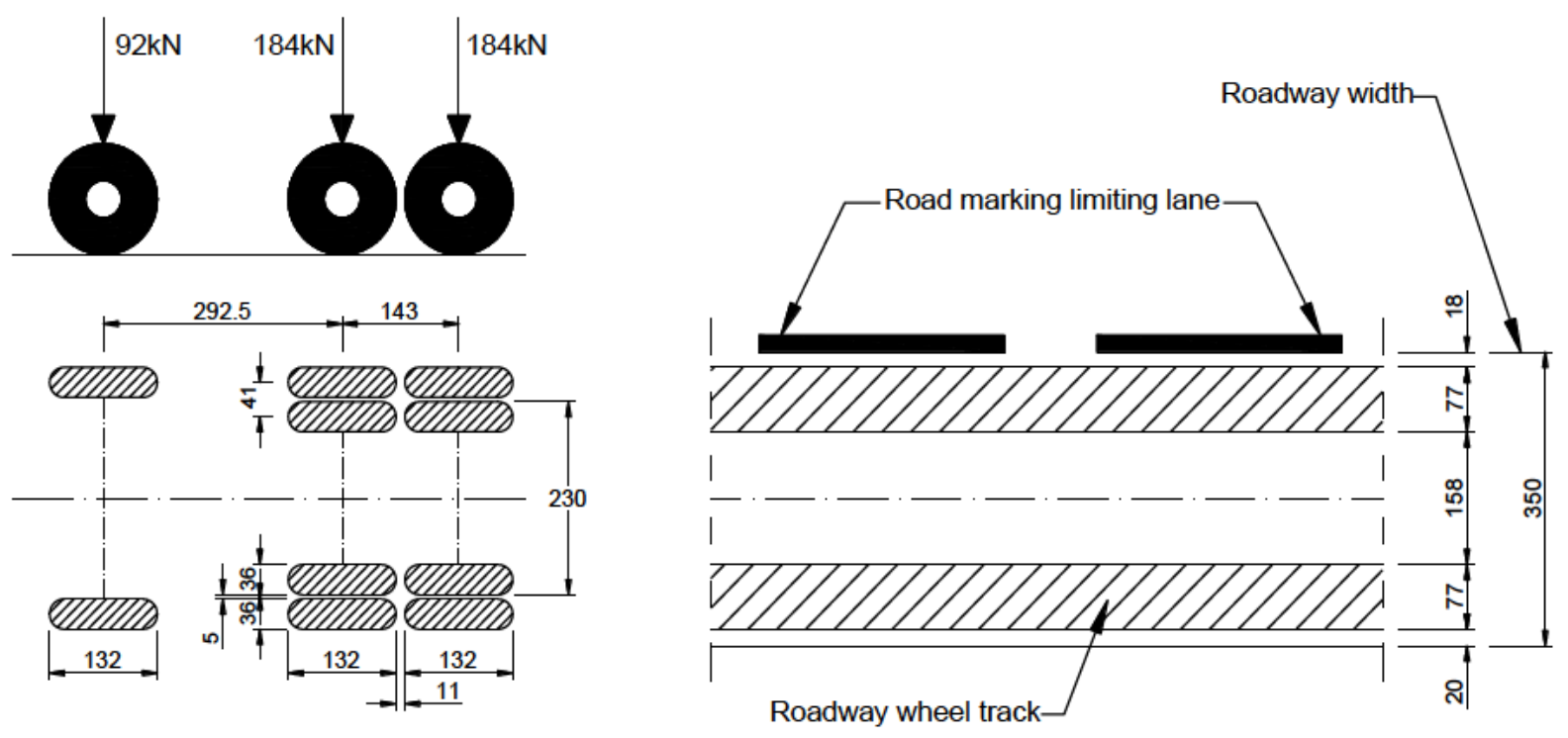

Figure 2. Wheel track on the road surface

According to the known theoretical principles for the reflective cracking propagation from the old degraded pavement to the asphaltic overlay, the shear stress is related to the transmission of effort to the crack in the concrete foundation. Bituminous material fatigue from the cyclic traffic loads is the main cause for the fracture initiation and propagation through the overlay (figure 3 ). The main cause for the fracture opening in the old concrete pavement is the contraction and expansion given by the seasonal temperature variations (figure $4)$.

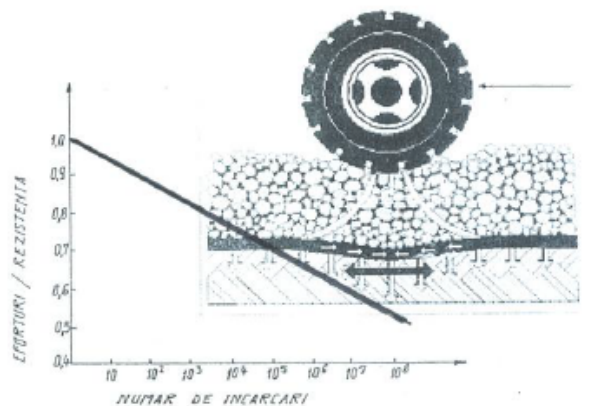

Figure 3. Material fatigue law
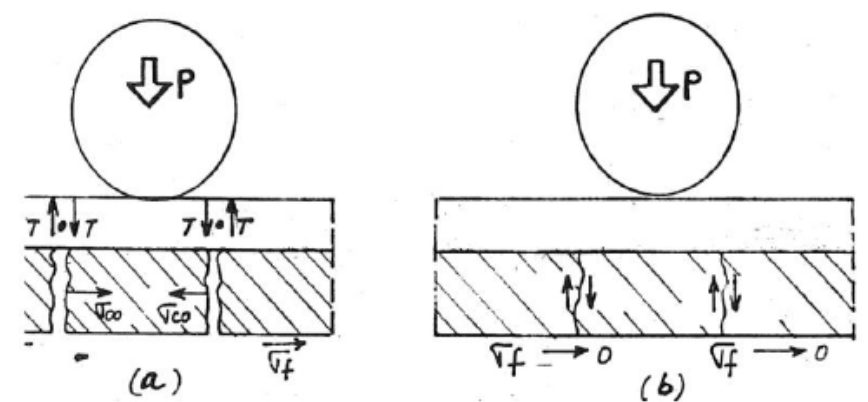

Figure 4. Effects in asphalt due to concrete fracture opening 
ROMANIAN JOURNAL

OF TRANSPORT INFRASTRUCTURE

Lobază Mihai Gabriel, Dicu Mihai,

Experimental modelling of asphaltic layers behaviour at reflective fracture from degraded pavements Parametric studies

\section{EXPERIMENTAL LABORATORY TEST STAND}

\subsection{Constructive disposal}

The constructive disposal of the stand, used for the experimental laboratory modelling of the reflective fracture in the asphaltic -old degraded concrete system, has the main scheme as in figure 5 and 6.

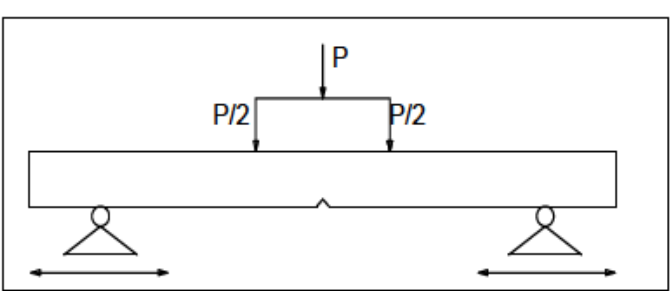

Figure 5. Constructive disposal of the test stand

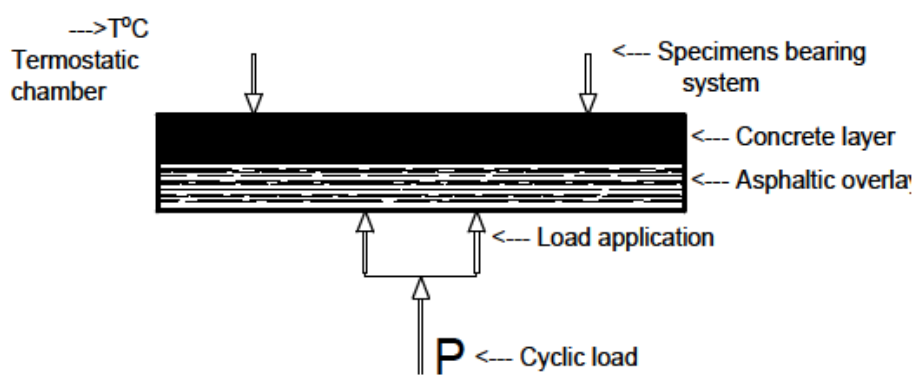

Figure 6. Mechanical functioning scheme of the cracking device with temperature control

The functioning scheme of the testing equipment for reflective cracking is similar to the four point bending test (figure 5), regulated by the laboratory testing standards. The difference between them is the "inversed" load application (figure 6), allowing the placement of a video camera (figure 7) for data acquisition regarding the fracture initiation and propagation through the test specimen (figure 8).

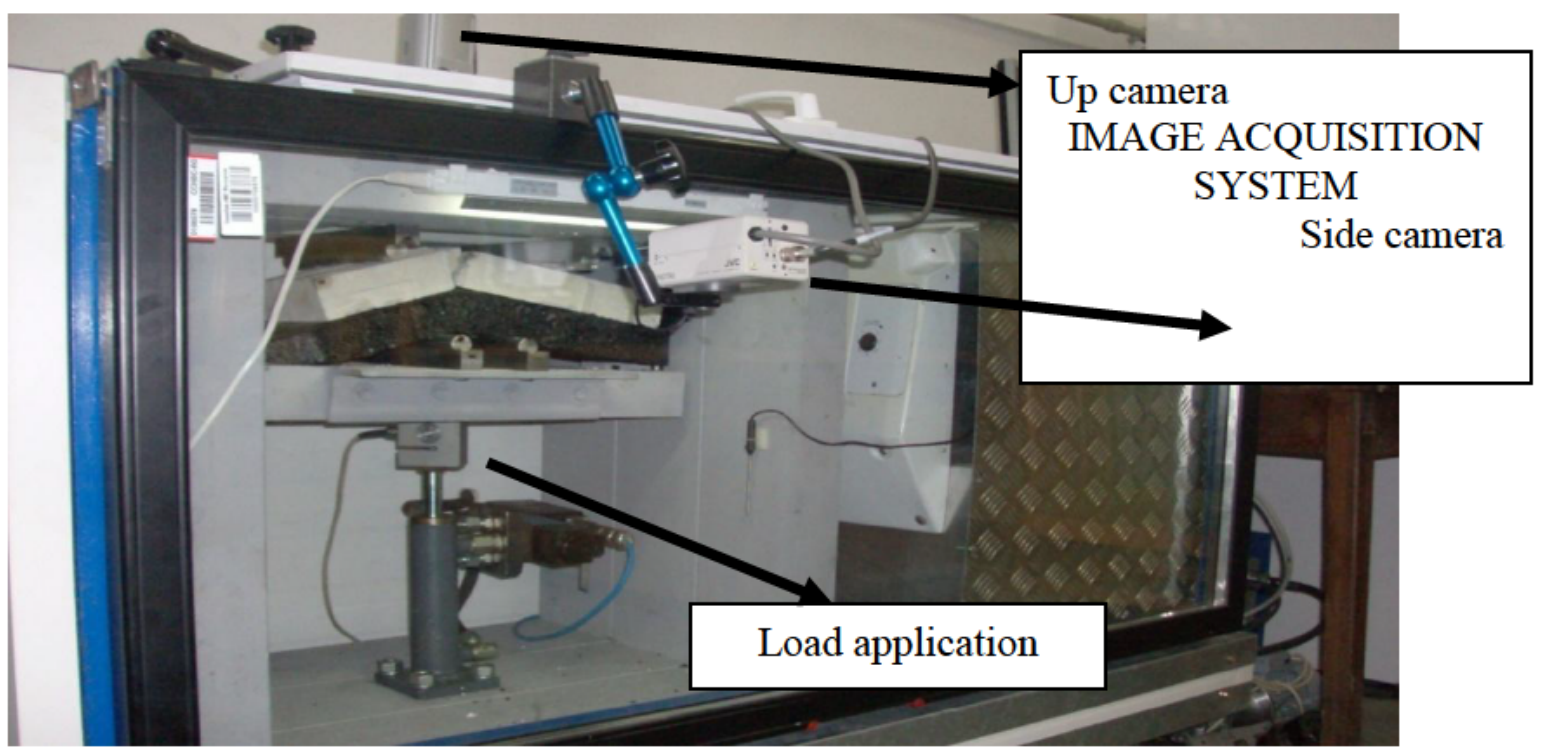

Figure 7. Video camera positioning for data aquisition 
ROMANIAN JOURNAL

OF TRANSPORT INFRASTRUCTURE

Lobază Mihai Gabriel, Dicu Mihai,

Experimental modelling of asphaltic layers behaviour at reflective fracture from degraded pavements Parametric studies

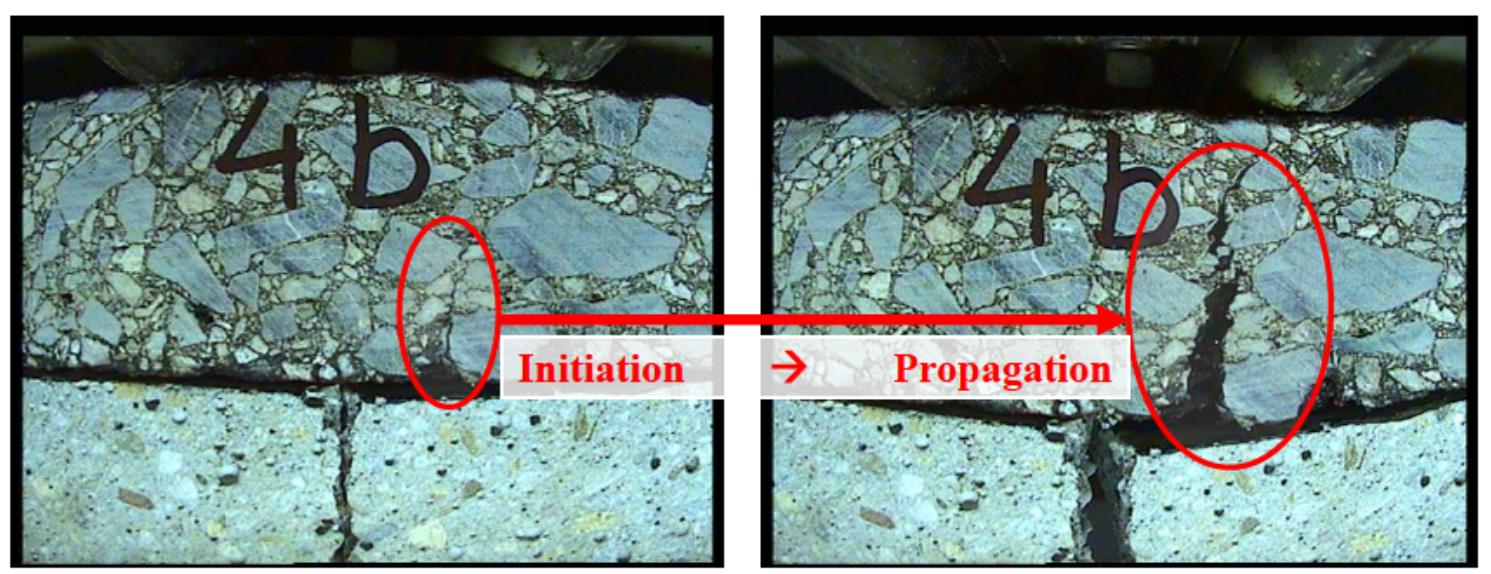

Figure 8. Fracture initiation and propagation through the asphaltic overlay of the experimental model

\subsection{Fracture parameters measured with this test stand}

With the help of this stand (the cracking device with temperature control) the following parameters can be measured by the video acquisition system (through imagistic processing) (figure 9 and 10):

- $\quad w=$ asphalt -concrete specimen deformation,

- $d b=$ existing fracture opening in the precracked concrete,

- $e=$ asphalt - concrete interface detachment in the fracture area,

- $f=$ asphaltic overlay fracture length,

- $d=$ asphaltic overlay fracture opening.

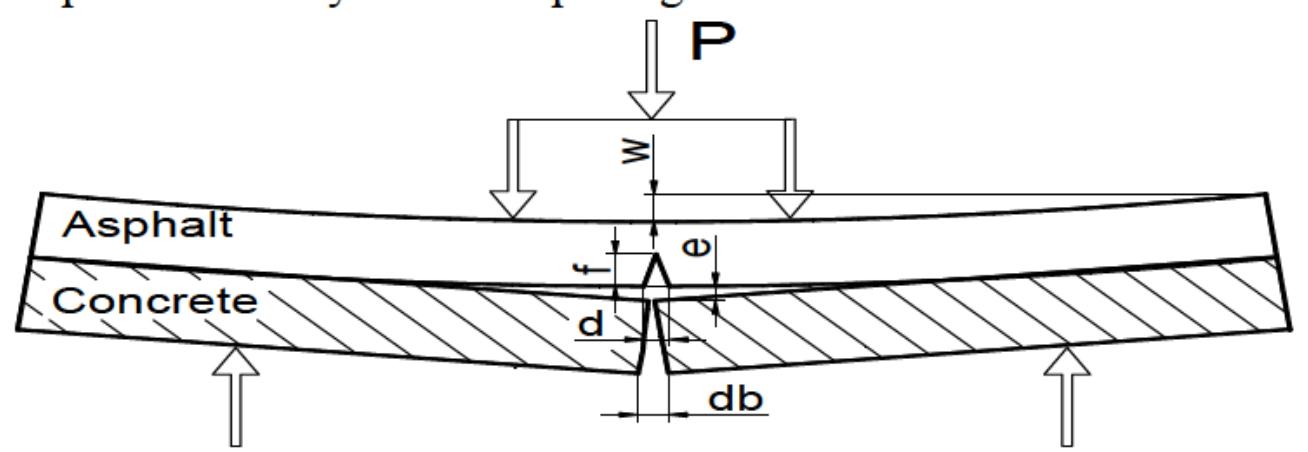

Figure 9. Parameters studied with the cracking device with temperature control 
ROMANIAN JOURNAL

OF TRANSPORT INFRASTRUCTURE

Lobază Mihai Gabriel, Dicu Mihai,

Experimental modelling of asphaltic layers behaviour at reflective fracture from degraded pavements Parametric studies
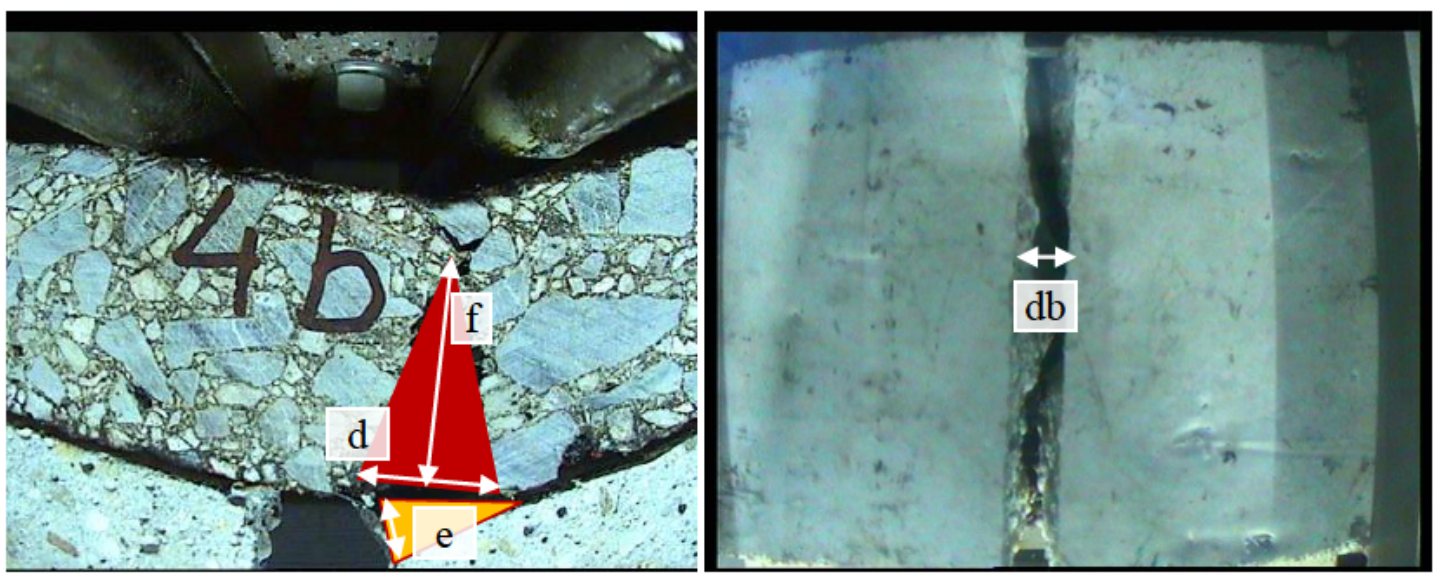

Figure 10. Asphalt overlay fracture opening (d) and length (f), existing concrete fracture detachment (e) and opening (db)

\subsection{Centralization of experimental data}

The data obtained during the laboratory experiment, on different specimens (asphaltic overlay on a precracked concrete), are processed as a table (table 1). Its graphical representation has the number of cycles $\left(\mathbf{n}_{\mathbf{c}}\right)$ on the horizontal, and on the vertical the measured parameters both automatically (w) and imagistic processing (d, f, e, db) (figure 11).

Table 1. Centralization of experimental data

\begin{tabular}{|c|c|c|c|c|c|}
\hline Specimen & $\mathbf{n}_{\mathbf{c}}$ & $\mathbf{d},(\mathrm{mm})$ & $\mathbf{f},(\mathrm{mm})$ & $\mathbf{w},(\mathrm{mm})$ & $\mathbf{d b},(\mathrm{mm})$ \\
\hline \multirow{6}{*}{} & 11612 & 0.00 & 0.00 & 3.7641 & 4.544 \\
\cline { 2 - 6 } & 12494 & 0.79 & 12.25 & 4.4073 & 5.103 \\
\cline { 2 - 6 } & 13712 & 1.26 & 22.61 & 5.3605 & 6.274 \\
\cline { 2 - 6 } & 13775 & 1.29 & 26.29 & 5.3728 & 6.274 \\
\cline { 2 - 6 } & 13838 & 1.30 & 27.53 & 5.4136 & 7.433 \\
\cline { 2 - 6 } & 14048 & 1.30 & 27.53 & 5.6807 & 7.433 \\
\cline { 2 - 6 } & 14069 & 2.83 & 29.52 & 5.693 & 7.433 \\
\cline { 2 - 6 } & 14195 & 3.63 & 34.25 & 6.0137 & 7.433 \\
\cline { 2 - 6 } & 14258 & 4.11 & 35.30 & 6.4033 & 9.976 \\
\cline { 2 - 6 } & 14300 & 4.71 & 36.11 & 6.6471 & 9.976 \\
\cline { 2 - 6 } & 14342 & 5.34 & 35.64 & 7.0853 & 9.976 \\
\cline { 2 - 6 } & 14363 & 5.65 & 34.70 & 7.319 & 9.976 \\
\cline { 2 - 6 } & 14426 & 6.77 & 35.56 & 8.4981 & 15.339 \\
\cline { 2 - 6 } & 14552 & 9.91 & 36.55 & 13.6902 & 15.339 \\
\hline
\end{tabular}


ROMANIAN JOURNAL

OF TRANSPORT INFRASTRUCTURE

Lobază Mihai Gabriel, Dicu Mihai,

Experimental modelling of asphaltic layers behaviour at reflective fracture from degraded pavements Parametric studies

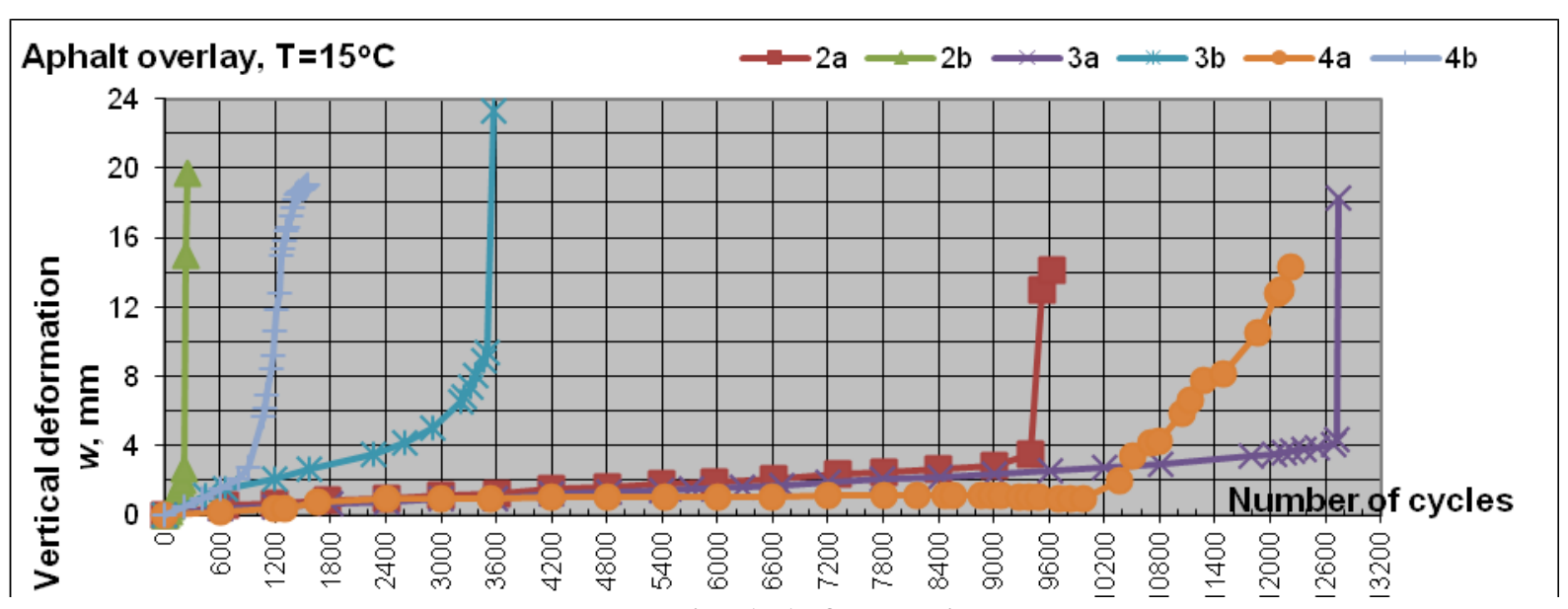

a. Vertical deformation

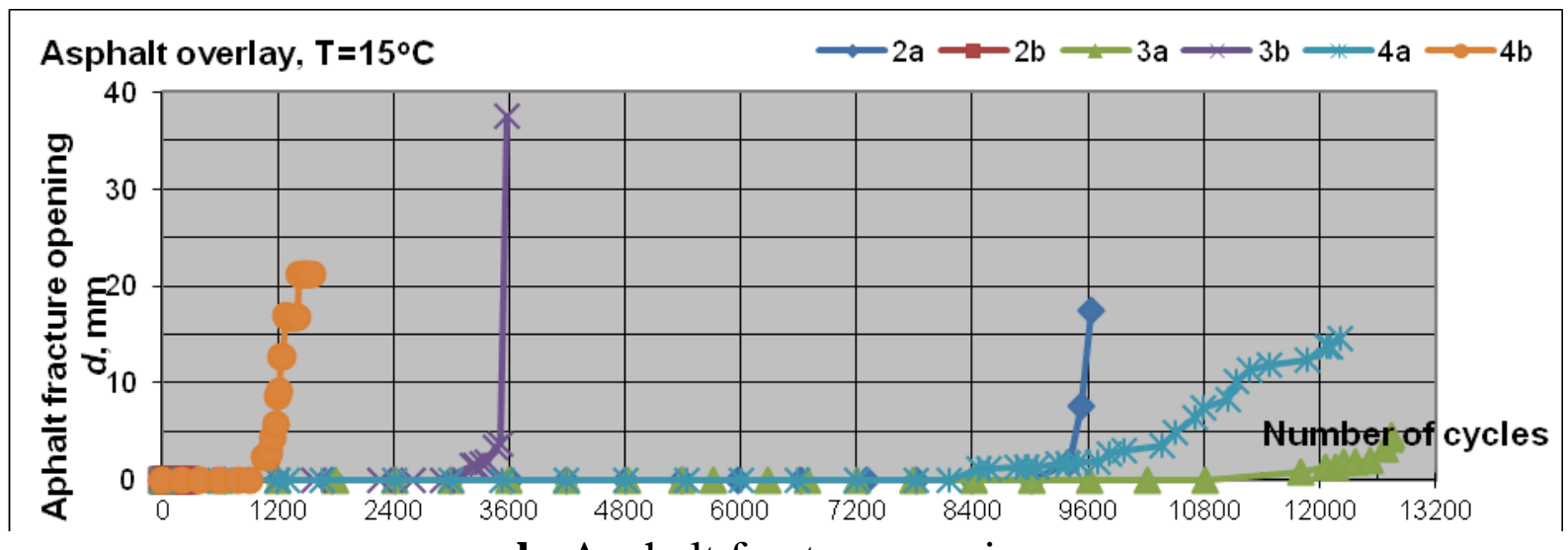

b. Asphalt fracture opening

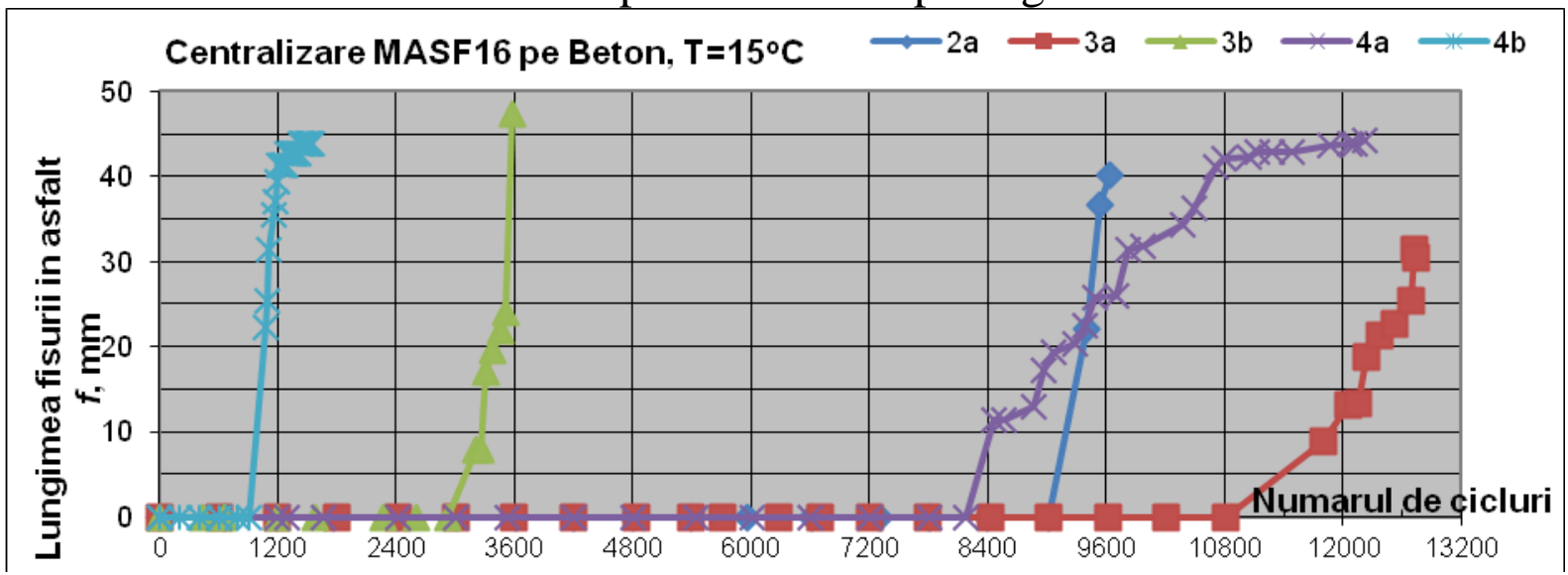

c. Asphalt fracture length depending on the number of cycles

Figure 11. Graphical representation of the reflective fracture parameters, according to different concrete fracture opening and asphalt-concrete bonding conditions 
ROMANIAN JOURNAL

OF TRANSPORT INFRASTRUCTURE

Lobază Mihai Gabriel, Dicu Mihai,

Experimental modelling of asphaltic layers behaviour at reflective fracture from degraded pavements Parametric studies

\subsection{Analysis parameters of the reflective cracking}

Analyzing the reflective cracking parameters allows obtaining the following phenomenological data processed through experimental modelling, analysis which expresses the performance of an asphaltic mixture utilized as an overlay:

- Fracture duration in accelerated conditions $\left(\mathrm{T}_{\mathrm{f}}\right)$

- Asphalt fracture opening (d)

- Asphalt -concrete detachment around the fracture area (e)

- The number of cycles at the fracture initiation and propagation $\mathbf{n}_{\mathbf{c}}$, at the opening and propagation on the asphaltic layer thickness $\mathbf{n}_{\mathbf{c f}}$ and at the failure of the overlay $\mathbf{n}_{\mathbf{c R}}=\mathbf{n}_{\text {ctot }}$.

- Vertical deformation (deflexion) at the fracture initiation and propagation $\mathbf{w}_{\mathbf{i}}$, at the fracture opening and propagation through the entire asphalt overlay $\mathbf{w}_{\mathbf{f}}$, at failure $\mathbf{w}_{\mathbf{f}}$ and at the crack appearance on the surface of the overlay $\mathbf{w}_{\mathbf{R}}$.

- Fracture opening in the existing concrete pavement (db)

- The fracture eccentricity position in asphalt compared to the fracture position in concrete, $\mathbf{e}_{\mathbf{i}}$ (initial), $\mathbf{e}_{\mathbf{f}}$ (final)

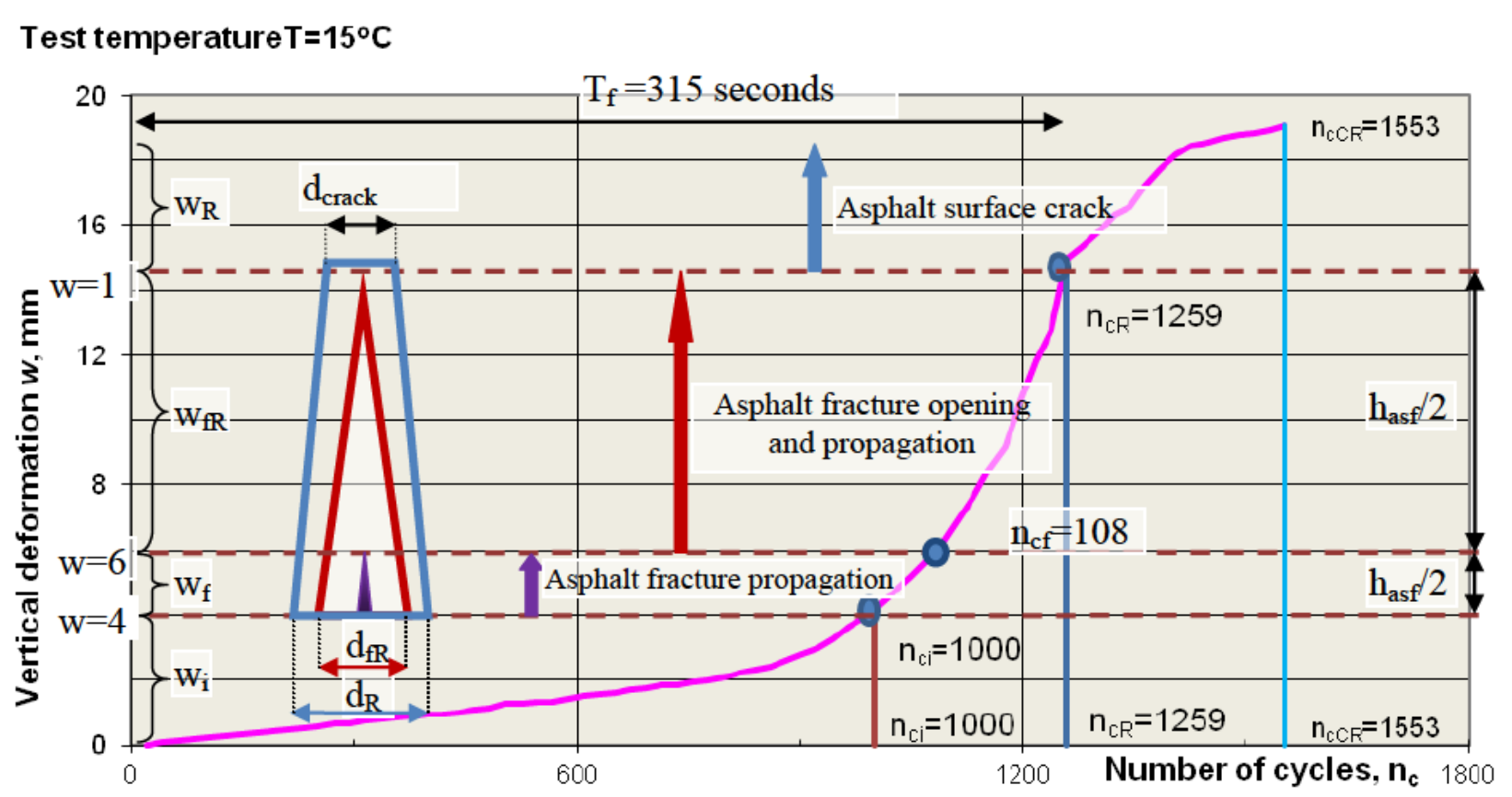

Figure 12. Analysis parameters for reflective cracking 


\section{MULTICRITERIAL INTERPRETATION OF THE REFLECTIVE CRACKING PROCESS}

The multicriterial interpretation is defined by a series of influencing criteria for the reflective cracking phenomenon in the asphaltic layer. The asphalt is used as an overlay for a precracked concrete pavement (due to its degradation in time).

Due to the fact that the treated road structure is composite (asphalt laid on a concrete pavement, in which every layer has different behaviour to traffic loads during its service life), the reflective cracking propagation from the concrete layer to the asphalt depends on the parameters presented in this paper, which must be analyzed by super positioning the effects.

The main influencing factors for reflective cracking are:

- dynamic loads that simulates the effects of road traffic, materialized in laboratory study through force intensity (F) and its application frequency (constant for the cracking device with temperature control)

- fracture transfer effect from the existing concrete crack, materialized through the opening parameter of the fracture in concrete $(\mathbf{d b})$.

- asphalt-concrete bonding, by evaluating the grip between the 2 different layers from the physical-mechanical characteristics point of view. This is materialized through $e, e_{i}$ and $e_{f}$ parameters, but also the detachment of the asphalt from the concrete layer in relation with the vertical deformation growth of the experimental model (w);

- Fracture initiation and propagation in the asphaltic layer, through fracture opening (d) and length (f), parameters which depends on the physicalmechanical characteristics of the bituminous mixture composing the ovelay.

As a consequence, the multicriterial interpretation of the reflective cracking for the rigid road structure rehabilitated with an asphaltic overlay requires a combined analysis of the influencing factors for the fracture transfer and propagation process from the precracked concrete to the asphalt overlay.

The influence factors are described under the form of parametric indexes:

- the index of cyclic loads cycles $I_{n c}$,

- the index of existing fracture opening in the concrete layer $I_{d b}$,

- the index of reflective fracture opening in the asphaltic layer $I_{d}$,

- the index of reflective fracture propagation in the asphaltic layer $I_{f}$,

The multicriterial analysis parameters capitalized through these indexes express the evolution of one parameter considering the ratio between a certain 
measured value and its final value (example: $\boldsymbol{I}_{\boldsymbol{f}}=\boldsymbol{f}_{/} \boldsymbol{f}_{\boldsymbol{t} \text { tot }}$, where $\mathbf{f}$-fracture length in the considered point, $\mathbf{f}_{\text {tot }}$-final fracture length).

For example, in the analysis made for the specimen that the measurements were calibrated, the direct links between the evolutions of some parameters are expressed (through mathematical processing and then graphical representation) like:

- opening $\mathbf{d}$, length $\mathbf{f}$ (asphalt fracture) and the number of cycles index until the fracture propagates in the entire asphaltic layer thickness $\mathbf{I}_{\mathbf{n c}}$, (figure 13),

- opening $\mathbf{d}$, length $\mathbf{f}$ (asphalt fracture) and concrete fracture opening $\mathbf{d b}$, (figure $14)$

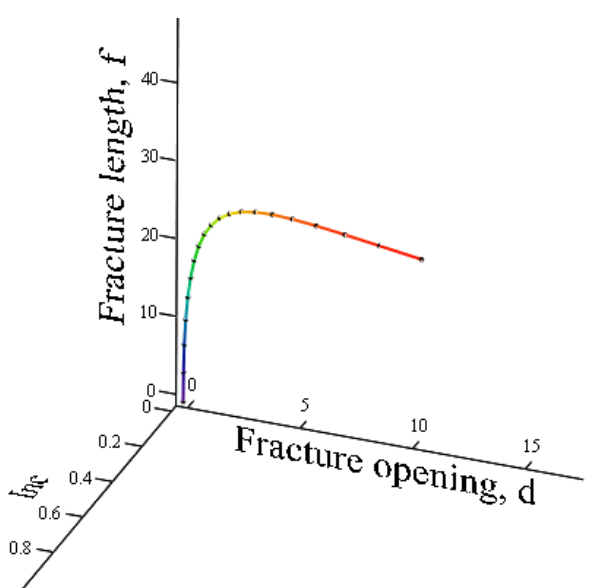

Figure 13. Tridimensional representation $\mathrm{d}, \mathrm{f}, \mathrm{I}_{\mathrm{nc}}$

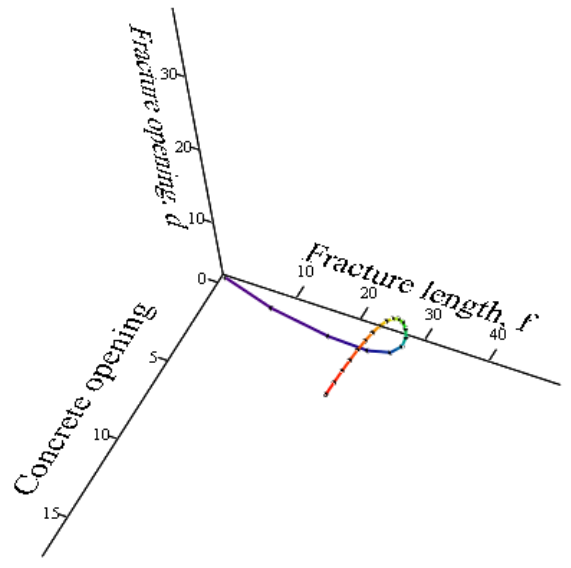

Figure 14. Tridimensional representation $\mathrm{d}, \mathrm{f}, \mathrm{db}$

\section{CONCLUSIONS}

Anticipating the evolution of the reflective cracking of an asphalt overlay on a degraded concrete pavement (cracked), can be done in laboratory through comparative studies between different asphaltic mixture designs with the help of a prototype stand named Cracking Device with Temperature Control.

The main advantage of this method represents the video data acquisition, which measures the parameters presented above during the experiment. This fracture influencing factors are further expressed as parametric indexes $\left(I_{n c}, I_{d b}\right.$, $\left.I_{d}, I_{f}\right)$.

We can use these indexes, calculated for different asphaltic mixture, to establish the optimal design from the reflective cracking resistance point of view. 


\section{ROMANIAN JOURNAL \\ OF TRANSPORT INFRASTRUCTURE}

Lobază Mihai Gabriel, Dicu Mihai,

Experimental modelling of asphaltic layers behaviour at reflective fracture from degraded pavements Parametric studies

Another advantage of this method is the test time, much lower than that needed for the experimental field studies. The method also shortens the time even to the standardized tests ( 4 point bending test) because of the way the load is applied (constant force in growing steps).

\section{BIBLIGRAPHY}

[1]. $\quad$ M. LOBAZĂ: "Cercetarea prin modelare structurală în laborator a efectelor traficului asupra sistemelor rutiere reabilitate “, Raport de cercetare nr. 1, conducător științific prof.dr.ing. Mihai DICU, 2012

[2]. M. LOBAZĂ: “Analiza prin interpretare statistică a soluțiilor obținute în regim accelerat în laborator la solicitări echivalente traficului rutier", Raport de cercetare nr. 2, conducător știinţific prof.dr.ing. Mihai DICU, 2013

[3]. $\quad$ M. LOBAZĂ: "Identificarea parametrilor de influență a propagării fisurării prin straturi asfaltice de protecție la îmbrăcăminți rutiere degradate", Raport de cercetare nr. 3, conducător științific prof.dr.ing. Mihai DICU, 2015

[4]. M. DICU: "Preocupări în domeniul analizei procesului de fisurare la îmbrăcăminți rutiere “, București, Editura CONSPRESS 2012

[4]. M. DICU: “ Fisurarea sistemelor rutiere mixte", Teza de doctorat, 1996 